\title{
Saliva cortisol in relation to aircraft noise exposure: pooled-analysis results from seven European countries
}

\author{
Clémence Baudin ${ }^{1 *} \mathbb{D}$, Marie Lefèvre ${ }^{1,2}$, Jenny Selander ${ }^{3}$, Wolfgang Babisch ${ }^{4}$, Ennio Cadum ${ }^{5}$, \\ Marie-Christine Carlier ${ }^{6,7}$, Patricia Champelovier ${ }^{8}$, Konstantina Dimakopoulou $^{9}$, Danny Huithuijs ${ }^{10}$, \\ Jacques Lambert ${ }^{7,8}$, Bernard Laumon ${ }^{11}$, Göran Pershagen ${ }^{12}$, Töres Theorell ${ }^{13}$, Venetia Velonaki ${ }^{14}$, \\ Anna Hansell ${ }^{15}$ and Anne-Sophie Evrard ${ }^{1}$
}

\begin{abstract}
Background: Many studies have demonstrated adverse effects of exposure to aircraft noise on health. Possible biological pathways for these effects include hormonal disturbances. Few studies deal with aircraft noise effects on saliva cortisol in adults, and results are inconsistent.

Objective: We aimed to assess the effects of aircraft noise exposure on saliva cortisol levels and its variation in people living near airports.

Methods: This study focused on the 1300 residents included in the HYENA and DEBATS cross-sectional studies, with complete information on cortisol sampling. All the participants followed a similar procedure aiming to collect both a morning and an evening saliva cortisol samples. Socioeconomic and lifestyle information were obtained during a face-to-face interview. Outdoor aircraft noise exposure was estimated for each participant's home address. Associations between aircraft noise exposure and cortisol outcomes were investigated a priori for male and female separately, using linear regression models adjusted for relevant confounders. Different approaches were used to characterize cortisol levels, such as morning and evening cortisol concentrations and the absolute and relative variations between morning and evening levels.
\end{abstract}

Results: Statistically significant increases of evening cortisol levels were shown in women with a $10-\mathrm{dB}(\mathrm{A})$ increase in aircraft noise exposure in terms of $L A$ eq, $16 \mathrm{~h}(\exp (\beta)=1.08 ; C 195 \%=1.00-1.16), L_{\text {den }}(\exp (\beta)=1.09 ; C 195 \%=1.01-$ 1.18), $L_{\text {night }}(\exp (\beta)=1.11 ; C \mid 95 \%=1.02-1.20)$. A statistically significant association was also found in women between a 10-dB(A) increase in terms of $L_{\text {night }}$ and the absolute variation per hour $(\exp (\beta)=0.90 ; C 195 \%=0.80-$ 1.00). Statistically significant decreases in relative variation per hour were also evidenced in women, with stronger effects with the $L_{\text {night }}(\exp (\beta)=0.89 ; C 195 \%=0.83-0.96)$ than with other noise indicators. The morning cortisol levels were unchanged whatever noise exposure indicator considered. There was no statistically significant association between aircraft noise exposure and cortisol outcomes in men.

Conclusions: The results of the present study show statistically significant associations between aircraft noise exposure and evening cortisol levels and related flattening in the (absolute and relative) variations per hour in women. Further biological research is needed to deepen knowledge of the pathway between noise exposure and disturbed hormonal regulation, and specially the difference in effects between genders.

Keywords: Epidemiology, Aircraft noise exposure, Saliva cortisol

\footnotetext{
* Correspondence: clemence.baudin@ifsttar.fr

'Univ Lyon, Université Claude Bernard Lyon1, ifsttar, umrestte, umr t_9405,

Cité des Mobilités, 25 avenue François Mitterrand, F-69675 Bron, France

Full list of author information is available at the end of the article
}

(c) The Author(s). 2019 Open Access This article is distributed under the terms of the Creative Commons Attribution 4.0 International License (http://creativecommons.org/licenses/by/4.0/), which permits unrestricted use, distribution, and reproduction in any medium, provided you give appropriate credit to the original author(s) and the source, provide a link to the Creative Commons license, and indicate if changes were made. The Creative Commons Public Domain Dedication waiver (http://creativecommons.org/publicdomain/zero/1.0/) applies to the data made available in this article, unless otherwise stated. 


\section{Introduction}

Aircraft noise exposure represents a major issue for public health policies. Impacts on human health are of growing concern, and many adverse effects have been evidenced [1]. Extensive information is available to quantify the burden of disease from aircraft noise exposure associated with annoyance, sleep disturbances, cardiovascular disease including hypertension [2-7], and altered cognitive performance among children [8,9]. A proposed biological process is the release of stress hormones with noise exposure, leading to disruption of hormonal rhythms by activating the SympatheticAdrenal-Medullary (SAM) axis and the HypothalamicPituitary-Adrenal (HPA) axis [10, 11]. Cortisol can be viewed as a stress indicator, and is easy to measure noninvasively [12]. Its concentration may be a clinical indicator of disturbed HPA axis activity, and therefore can be used to assess chronic stress effects due to noise exposure [13]. Specific roles of cortisol include regulation of blood glucose levels, lipolysis, immune suppression, and regulation of blood pressure [14]. The cortisol secretion follows a circadian rhythm in the absence of stimuli: levels decline slowly throughout the day, from a peak in the early morning (20-30 min after awakening) to a nadir in the evening [15]. Cortisol can easily be measured in saliva and this reliably reflects the serum-free cortisol concentration [16].

The majority of the studies have focused on average levels of cortisol at specific times of the day [17, 18]. However, when subjects are chronically exposed to high levels of energy mobilization after exposure to a stressor, the regulation of the cortisol response could be disturbed. This may be in the form of inability to lower cortisol during the calmer part of the day with no decrease in cortisol when the subject is expected to fall asleep. After long intensive periods without possibility to recuperate, the subject may develop a low flat curve, which is associated with inability to mobilize cortisol when it is needed [19]. Several studies showed an association between long-term stress exposure and a flattening of the diurnal cortisol rhythm across the day [20-22]. The variability of cortisol during the day could therefore be used as an indicator of a disturbed HPA axis regulation.

Many studies have been carried out on the relationship between noise exposure and cortisol levels, but conclusions are still unclear [12]. Biological responses may differ depending on the source (occupation, road traffic, rail or air) and characteristics of the study population (gender, age) [23]. Studies on aircraft noise exposure and cortisol levels have mainly focused on children's populations. The main studies to date on adults were a subset of HYENA (HYpertension and Exposure to Noise near Airports) [24] and DEBATS (Discussion on the health effects of aircraft noise) [5] projects. The HYENA study analysis found increases in morning saliva concentrations with aircraft noise exposure in women only [17], while DEBATS found higher evening but not morning cortisol in both men and women [25].

The present HYDE (HYENA + DEBATS) project aims to combine both HYENA and DEBATS datasets in order to elucidate the effects of aircraft noise exposure on saliva cortisol levels. The HYENA study included persons living near one of seven major European airports [London Heathrow (United Kingdom), Berlin Tegel (Germany), Amsterdam Schiphol (the Netherlands), Stockholm Arlanda and Bromma (Sweden), Milan Malpensa (Italy), and Athens International Airport Eleftherios Venizelos (Greece) Airports]. Specifically, the HYDE present project added to the HYENA study the three French airports included in the DEBATS study: Lyon Saint Exupéry, Toulouse-Blagnac, and Paris-Charles de Gaulle - the latter being a major European airports in term of passenger numbers [26]. Combination of HYENA and DEBATS enabled a higher number of participants to be included in the analyses, resulting in an increase in statistical power, and extending the scope of the results. As gender differences in production of corticosteroid-binding globulin have been shown [27], the higher number of participants in the HYDE study allowed us to investigate the association between aircraft noise exposure and cortisol secretion for male and female separately. Moreover, the HYDE study also provided an opportunity to consider a new approach based on the relative variation in cortisol levels per hour taking into account time between measurements as well as morning and evening levels.

\section{Methods \\ Study population}

The main HYENA study included participants aged 4570 at the time of the interview, living near one of seven major European airports in six countries. Participants were selected at random from available registers (e.g. registration office, electoral roll, health service). Data were collected on 4861 participants between 2004 and 2006 [24]. The sub sample for saliva sampling was randomly selected from the participants in the main study. Priority was given to participants with the highest and lowest levels of exposure to aircraft noise in each country. The lowest level of exposure corresponds to $<50$ $\mathrm{dB}(\mathrm{A})$ in terms of LAeq, $24 \mathrm{~h}$ in all countries. The highest level of exposure was not the same in all countries: it varies from $>60 \mathrm{~dB}(\mathrm{~A})$ in Italy, Greece, the Netherlands and Sweden to $>65 \mathrm{~dB}(\mathrm{~A})$ in Germany and $>69 \mathrm{~dB}(\mathrm{~A})$ in the UK. With the purpose to recruit 84 subjects from each of the six participating countries, complete 
information for cortisol samples were finally provided for a total number of 473 participants.

The main DEBATS study included people over 18 years of age at the time of the interview, living in the study area around three French international airports [6]. Participants were selected at random from a phone directory, based on their address in the study area and contacted by phone. Cortisol sampling were collected on all 1244 participants (549 men and 695 women) in 2013 [5]. Complete information for cortisol samples were provided for 1199 of them.

In both studies, all the participants responded to a questionnaire during a face-to-face interview at their place of residence. This questionnaire collected information on demographic and socioeconomic characteristics, lifestyle factors including smoking habits, alcohol consumption, and physical activity, personal medical history in terms of sleep disturbance, cardiovascular diseases, anxiety, depressive disorders, medication use, and annoyance due to noise exposure. Blood pressure, anthropometric measurements (weight and height), and saliva samples (cortisol concentrations) were recorded.

As cortisol levels are related to the circadian rhythm, which is sensitive to individual schedule, participants with a typical working (shift workers, working at night) and/or typical sleeping patterns were excluded from the pooled analyses $(N=341)$. Other exclusions were made for participants with missing information on cortisol samples (concentrations, dates, and times) and those with $24 \mathrm{~h}$ or more between the both saliva samplings.

The final pooled analyses were carried out on $\mathrm{N}_{\mathrm{HYDE}}=$ 1300 participants (359 from HYENA and 941 from DEBATS, including 555 men and 745 women) who had completed information for all the covariates included in the model (Fig. 1).

Each centre's ethical committee gave study approval and each participant provided written informed consent.

\section{Cortisol measurements}

In HYENA, participants received a kit with test tubes (Sarstedt, Nümbrecht, Germany) and instructions the week before the interview. Samples had to be collected the day before the interview and given to the staff during the interview. Tubes were sent to, centrifuged and frozen in laboratory in each of the participating countries. When all samples had been received in each country, saliva tubes were sent to Karolinska Institutet laboratory (Stockholm, Sweden) for analysis. Cortisol levels in saliva were determined by the Spectria cortisol coated tube radioimmunoassay kit (Orion Diagnostica, Espoo, Finland). In DEBATS, participants received a kit with test tubes (Sarstedt, Nümbrecht, Germany) and instructions during the interview. Samples had to be collected and given to the staff in the days following the interview.
Tubes were sent to, and frozen in a laboratory in Lyon (France). Cortisol levels in saliva were determined by the cortisol saliva ELISA kit (IBL international, Hamburg, Germany).

Instructions for the procedure in measurements were similar in both studies. Participants were requested to collect a sample $30 \mathrm{~min}$ (in HYENA) (corresponding usually to the peak in cortisol concentration) or immediately (in DEBATS) after awakening, and another one just before going to bed in the evening (which usually coincides with the nadir in cortisol concentration). Tooth brushing, smoking, and food and drink intake were to be avoided $30 \mathrm{~min}$ before each sampling. Each of the test tubes included a small cotton swab that participants were instructed to put in their mouth and to chew until it was completely soaked in saliva. Then, the swab had to be placed in the test tube and stored in a fridge, after writing date and time on the label of the tube. All samples were analysed simultaneously in duplicate.

\section{Aircraft noise exposure assessment}

Aircraft noise exposure was estimated at the place of residence of the participants, in front of the buildings. For all countries except the UK, aircraft noise levels were provided from the "Integrated Noise Model" (INM) [28]. The INM is an internationally well-established computer model that evaluates aircraft noise impacts in the vicinity of airports and outputs noise contours for an area. The UK used the national Aircraft Noise Contour Model (ANCON v 2) [29], similar to the INM model. The INM and ANCON models require the following input data: actual measurements, the approach and departure routes or flight tracks, the traffic upon them in terms of the numbers of different aircraft types, the dispersion of individual flight tracks, the average flight profiles (of height, noise emission and speed) of the different aircraft types [30, 31].

Outdoor aircraft noise exposure was assessed in 1$\mathrm{dBA}$ intervals for each participant by linking his/her home address to the noise contours using geographical information systems (GIS) methods. Four noise indicators referring to three different periods of the day were derived and used for the statistical analyses: $\mathrm{L}_{\text {den }}$, $\mathrm{L}_{\text {Aeq,24h}}, \mathrm{L}_{\text {Aeq,6h-22h}}$, and $\mathrm{L}_{\text {night. }}$ The $\mathrm{L}_{\text {den }}$ is an indicator for the $24 \mathrm{~h}$ period among others defined in the EU directive 2002/49 [32] relating to the assessment and management of environmental noise. It is defined as the weighted average of sound levels during daytime (06:00 to $18: 00$ or $7: 00$ to $19: 00$, depending on the country), evening (18:00 to $22: 00$ or 19:00 to 23:00), and nighttime (22:00 to $6: 00$ or 23:00 to 7:00), where evening and night sound pressure levels received a $5 \mathrm{~dB}(\mathrm{~A})$ and a 10 $\mathrm{dB}(\mathrm{A})$ penalty respectively to reflect the extra sensitivity to noise during the evening and the night. The $\mathrm{L}_{\mathrm{Aeq}, 24 \mathrm{~h}}$, 


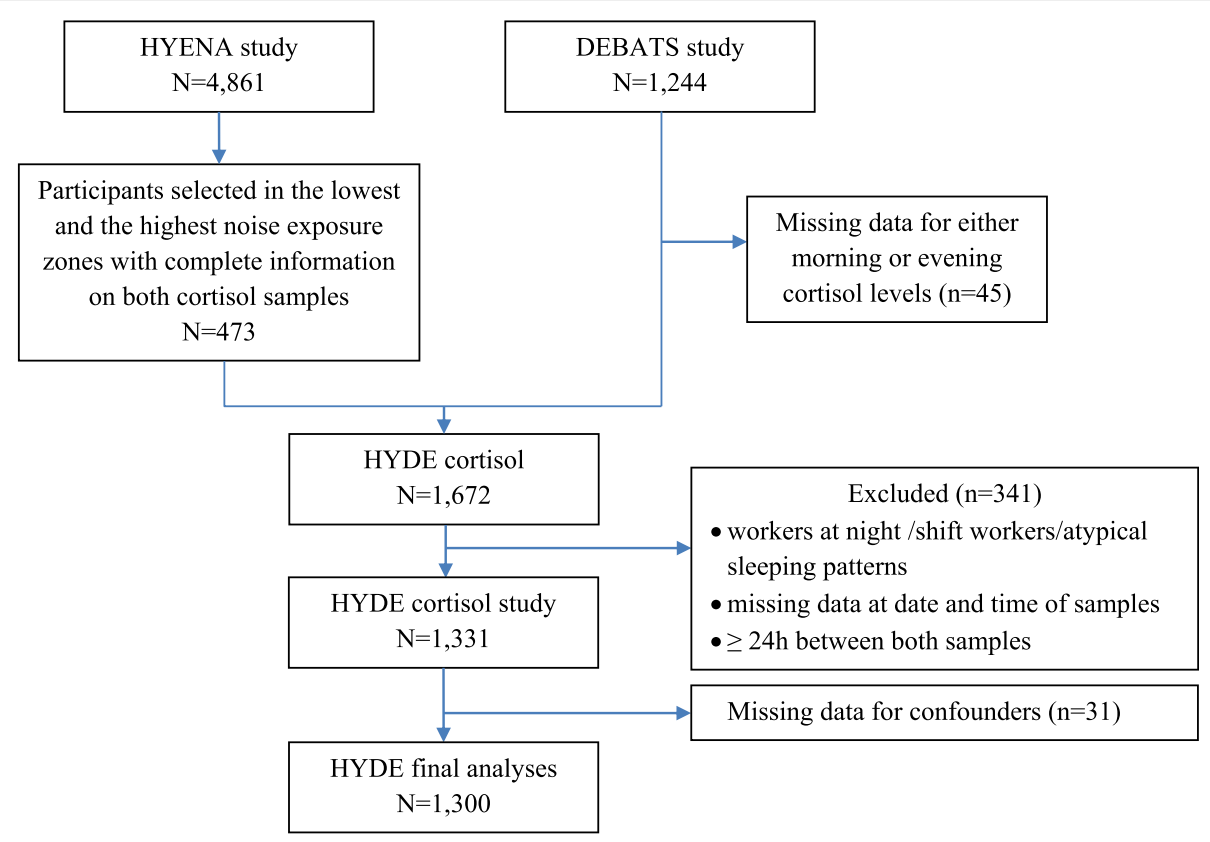

Fig. 1 Flow chart of HYDE cortisol participants

$\mathrm{L}_{\text {Aeq,6h-22h }}$ and $\mathrm{L}_{\text {night }}$ correspond to average sound levels during the corresponding period of time.

\section{Annoyance due to aircraft noise}

Aircraft noise annoyance was assessed using the ISO/ Icben (International Commission on the Biological Effects of Noise) recommended question [33], both in HYENA and in DEBATS: "Thinking about the last 12 months when you are here at home, how much does aircraft noise bother, disturb or annoy you?"

Then, in HYENA, the standard numeric scale was used for night-time and daytime annoyance separately (range 0-10). In the present HYDE study, an average score between night-time and daytime score was calculated, and participants with an average score $\geq 8$ were considered as being highly annoyed.

In DEBATS, the standard verbal scale was used with five possible answers: extremely, very, moderately, slightly or not at all. Extremely or very annoyed participants were considered as being highly annoyed.

\section{Noise sensitivity}

In HYENA, noise sensitivity was assessed with the shortform of the Weinstein scale [34] including 10 items where people were asked to evaluate how much (from 1 to 6) they agreed with different statements about noise. One question concerned sensitivity to noise.

In DEBATS, the following 5-point question was used to assess noise sensitivity: "Regarding noise in general, compared to people around you, do you think that you are: much less sensitive than, or less sensitive than, or as sensitive as, or more sensitive, or much more sensitive than people around you?"

The sensitivity question in HYENA was assimilated to the one in DEBATS as follows: 1 corresponds to "much less sensitive", 2 to "less sensitive", 3 and 4 to "as sensitive", 5 to "a little more sensitive" and 6 to " much more sensitive".

\section{Confounders}

Information about major potential confounders were obtained from the face-to-face interview and were a priori included in the models: country, gender (dichotomous), age (continuous), BMI (continuous), smoking habits (five categories: non-smoker; ex-smoker; 1-10 units/day; 1120 units/day; > 20 units/day), alcohol consumption (4 categories: teetotaller; 1-7 units a week; 8-14 units/ week; > 14 units/week), physical activity ( 2 categories: no or a little; regular), and education level (coded as quartiles of number of years in education previously standardized by country means). Education level was included in the models as a possible confounder, as a proxy for income. Indeed, this variable was available in all countries, unlike the income that is forbidden to be collected in the UK.

\section{Statistical analysis}

The HYENA and the DEBATS datasets were first pooled and harmonized according to common variables. Then, different outcomes were tested, as cortisol is a biological measure following a circadian rhythm. 1) We analysed the morning $\left(C_{1}\right)$ and the evening levels $\left(C_{2}\right)$ in cortisol 
separately $\left(\right.$ nmol. $\left.\mathrm{L}^{-1}\right) .2$ ) We investigated the average variation in cortisol per hour $\left(\mathrm{nmol} . \mathrm{L}^{-1} \cdot \mathrm{H}^{-1}\right)$ between both samplings (calculated as $\left(\mathrm{C}_{1}-\mathrm{C}_{2}\right) /\left(\left|\mathrm{T}_{1}-\mathrm{T}_{2}\right|\right)$ where $\mathrm{T}_{1}$ corresponds to sampling time for $\mathrm{C}_{1}$ and $\mathrm{T}_{2}$ corresponds to sampling time for $\mathrm{C}_{2}$ ). The variation in cortisol was firstly defined in the absolute difference between evening and morning saliva sample concentrations because cortisol levels are expected to decrease over the day. As time between both samplings varied between participants, the variation in cortisol was divided by the time in hours between the two samplings to enable comparisons. 3) We tested the average relative-variation in cortisol per hour between both samplings $\left[\left(C_{1}-C_{2}\right) / C_{1}\right] /$ $\left(\left|\mathrm{T}_{1}-\mathrm{T}_{2}\right|\right)$. The variation in cortisol per hour was divided by the morning level as reference level, thus allowing for individual differences in cortisol levels and also for potential measurement differences between HYENA and DEBATS related to sampling equipment and laboratory analysis.

Each of these outcomes were firstly log-transformed to compensate for a non-normal distribution. Then, we analysed each outcome in relation to aircraft noise exposure using linear regression, adjusted for the confounders. As a literal interpretation for log-linear results, considering $\mathrm{Y}$ as a cortisol outcome, the expected value of $Y$ is multiplied by exp. $(\beta)$ for each 1-unit increase in $X$. Thus, to interpret results in our study, the given value $\exp .(\beta)$ is the multiplier to be applied to the considered cortisol outcome in order to get its expected value with a $10-\mathrm{dB}(\mathrm{A})$ increase in noise level.

Studies reported consistently higher cortisol values with ELISA method (applied in the DEBATS study) than with RIA method (applied in the HYENA), for same samples. Compared to controls, RIA gave results much closer to the expected value than ELISA did [33]. Although measurements concerned only 10 samples, Baecher et al. (2013) published Passing and Bablock regression of salivary cortisol results reported by immunoassay systems related to a reference (35). Regression equations showed a strong linear relationship between ELISA and RIA methods: RIA $=0.92$ (95\% CI: $0.87-1.03) \times$ ELISA-0.19 (95\% CI: -0.35 to -0.04$) ; r=$ 0.993 . This last equation was used in sensitivity analyses to make the levels of cortisol concentrations between the two studies comparable.

As gender differences in production of corticosteroidbinding globulin have been shown [27], analyses were carried out for male and female separately. Moreover, in previous analyses carried out on HYENA participants, no substantial differences in effect of noise have been shown between countries [36, 37]. Therefore, the interaction term between country and noise exposure was tested but as it was not statistically significant, it was not included in the final model.
The stability of the results was tested in sensitivity analyses, in which one country from the HYENA study was removed in turn from analyses.

As women are prone to hormonal disturbances with menopause, sensitivity analyses were also carried out for women under and above 50 years of age separately $(N=$ 286 and $N=459$ respectively).

Some evidence suggests that annoyance may be on the causal pathway between noise exposure and hypertension $[38,39]$ or saliva cortisol [40]. Noise sensitivity can be conceptualized as a modifier or mediator of the effects of noise exposure on the outcome measured [41]. Thus, these factors have been both included in an additional model as covariates, and regarded as factor of interest instead of noise levels. However, when they were included as covariates, they did not modify the results, so these factors were not included in the final models.

Coefficients and 95\% CIs were calculated to show the average variation in outcomes for a $10-\mathrm{dB}(\mathrm{A})$ increase in noise. All statistical analyses were performed with SAS software V. 9.4 (SAS Institute, Cary NC) using the GLM procedure.

\section{Results}

Participation rates differed between countries, from approximately $30 \%$ in France, Germany, Italy, and the UK to $46 \%$ in the Netherlands, $56 \%$ in Greece, and $78 \%$ in Sweden. Figure 2 shows noise exposure levels by country and gender. The four noise indicators were highly correlated (correlation coefficients between 0.80 and 0.99). Participants from the UK were more likely to be exposed to higher noise levels compared to participants from other countries $(p<0.001)$. Characteristics of the study population, stratified by categories of noise exposure in terms of $\mathrm{L}_{\mathrm{den}}$ are presented in the Table 1. Few differences appeared between noise categories. They are related to alcohol intake in men $(p=0.006)$ and physical activity in women $(p=0.003)$.

There was no statistically significant gender difference for the cortisol levels (Table 2): geometric means for morning levels were slightly higher for men compared to women (20.3 nmol. $\mathrm{L}^{-1}$ and $19.9 \mathrm{nmol} . \mathrm{L}^{-1}$ respectively), whereas geometric means for evening levels were slightly lower for men compared to women $\left(3.9 \mathrm{nmol} . \mathrm{L}^{-1}\right.$ and $4.0 \mathrm{nmol} . \mathrm{L}^{-1}$ respectively). Men showed a slightly higher geometric mean for the variation per hour than women $\left(1.4 \mathrm{nmol} . \mathrm{L}^{-1} \cdot \mathrm{H}^{-1}\right.$ and $1.2 \mathrm{nmol} . \mathrm{L}^{-1} \cdot \mathrm{H}^{-1}$ for men and women respectively.) The geometric means for the average relative-variation per hour in men and in women were statistically and significantly different $(0.07$ and 0.06 respectively $(p=0.037)$ ).

Crude and adjusted linear regression coefficients after exponentiation for each of the cortisol outcomes (morning and evening cortisol levels, variation per hour, and 


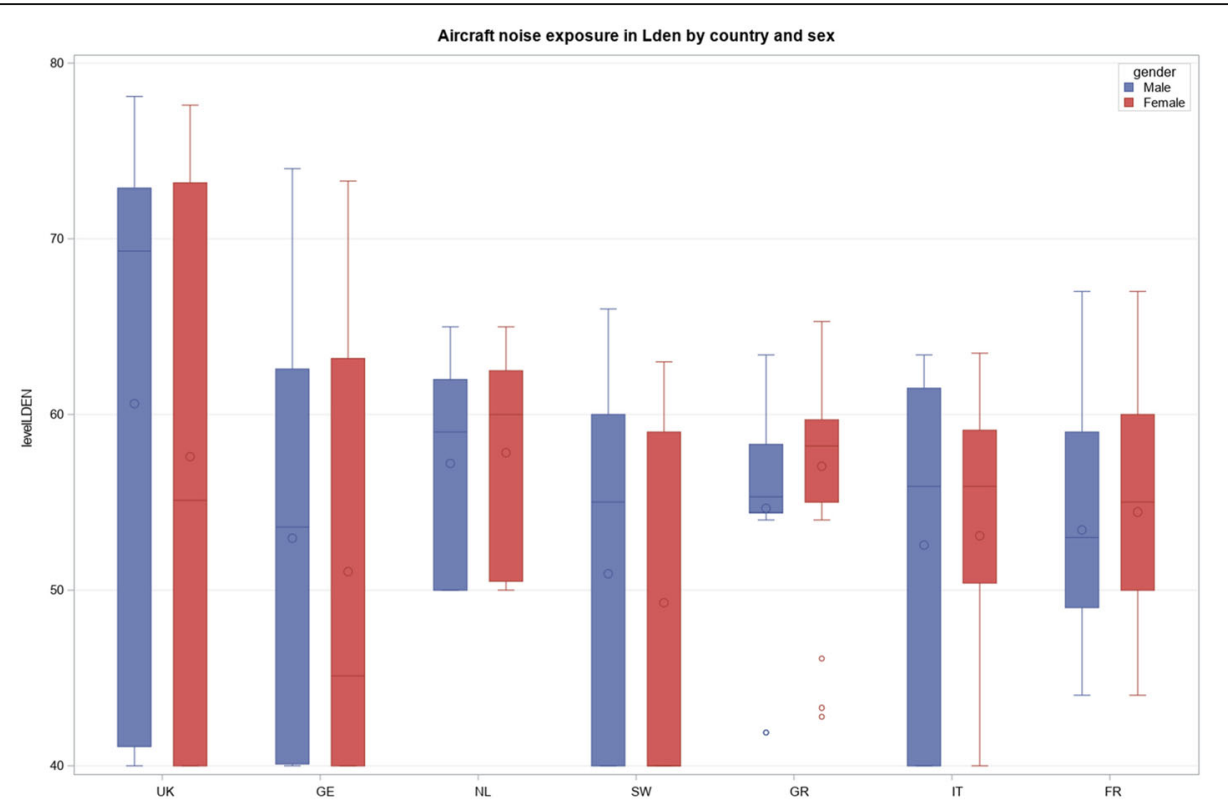

Fig. $2 L_{\text {den }}$ levels by country and sex. (UK: United Kingdom; GE: Germany; NL: The Netherlands; SW: Sweden; GR: Greece; IT: Italy; FR: France)

relative-variation per hour) in relation to aircraft noise levels are shown in Table 3. Analyses were performed for each noise indicator separately. No statistically significant association was found in men, for any of the cortisol outcomes, or noise indicators, both for univariate and multivariate analyses. Statistically significant crude estimates were shown in women only for the $\mathrm{L}_{\text {night }}$ in relation to the evening level, and for all the noise indicators in relation to the relative variation. For multivariate analyses, aircraft noise levels were not related to the morning concentration of cortisol, but were associated with an increase in evening cortisol concentration $(\exp (\beta)=1.08, \mathrm{CI} 95 \% 1.00-1.16$ for a $10-\mathrm{dB}(\mathrm{A})$ increase in $L_{\text {eq, } 16 h}$; exp. $(\beta)=1.09$, CI95\% $1.01-1.18$ for a 10 $\mathrm{dB}(\mathrm{A})$ increase in $\mathrm{L}_{\text {den }}$; exp. $(\beta)=1.11$, CI95\% $1.02-1.20$ for a $10-d B(A)$ increase in $L_{\text {night }}$ - while the relation between evening level and $\mathrm{LA}_{\mathrm{eq}}$, 24h was borderline significant exp. $(\beta)=1.08$, CI95\% $1.00-1.17$ per $10-\mathrm{dB}(\mathrm{A})$ increase) in women. For cortisol variation per hour, an association at the borderline of the statistical significance was found with $L_{\text {night }}$ suggesting a $11 \%$-decrease in the average difference between both samplings $(\exp (\beta)=$ 0.89 , CI95\% 0.80-1.00 per 10-dB(A) increase). Considering the relative-variation per hour, statistically significant associations were seen for a decrease of the relative difference between both samplings, whatever the noise indicator (a decrease of 8 to $11 \%$ according to the considered noise indicator). The strongest association was found for the $L_{\text {night }}$ exposure $(\exp (\beta)=0.89, \quad$ CI95\% $0.83-0.96$ per $10-\mathrm{dB}(\mathrm{A})$ increase).

No obvious differences were observed when noise annoyance or noise sensitivity were included in the model.
When these factors were included in the models as factor of interest instead of noise levels, results did not show statistically significant association with cortisol outcomes, except an association between aircraft noise annoyance and the relative variation of cortisol in women only $(\exp (\beta)=0.82$, CI95\% 0.72-0.93 for highly annoyed women compared to not annoyed women).

When analyses were carried out removing one country from the HYENA study in turn from the study population, results were similar to those found for the whole study population (See Additional file 1: Table S1).

Analyses carried for women under or above 50 years of age showed statistically significant associations between aircraft noise exposure and cortisol outcomes in women under 50, whereas no statistically significant association was found in women 50 and older (See Additional file 1: Table S2).

Finally, the results of the sensitivity analyses with the adjusted cortisol levels (results not shown) to overcome differences in the cortisol determination method (ELISA versus RIA method) were similar to the results in Table 3.

\section{Discussion}

This study provides some support for the hypothesis that psychological stress induced by aircraft noise exposure, results in disturbed cortisol regulation, with an increase in evening cortisol levels and a flattening of the usual (absolute or relative) variation per hour. The results of the present study are partly in line with those found based on the DEBATS participants only [25], where similar conclusions were drawn, but in that study 
Table 1 HYDE study population characteristics stratified by aircraft noise categories by sex sub-groups $\left(L_{\text {den }}\right)$

\begin{tabular}{|c|c|c|c|c|c|c|c|c|c|c|c|c|}
\hline & \multicolumn{6}{|l|}{ MALE } & \multicolumn{6}{|c|}{ FEMALE } \\
\hline & \multicolumn{6}{|l|}{$L_{\text {den }}$} & \multicolumn{6}{|l|}{$\underline{L_{\text {den }}}$} \\
\hline & $\begin{array}{l}<50 \\
\mathrm{~dB}(\mathrm{~A})\end{array}$ & $\begin{array}{l}50-54 \\
d B(A)\end{array}$ & $\begin{array}{l}55-59 \\
d B(A)\end{array}$ & $\begin{array}{l}\geq 60 \\
d B(A)\end{array}$ & $\begin{array}{l}\mathrm{N} \\
\text { total }\end{array}$ & $\begin{array}{l}p\left(x^{2}\right) \text { or } \\
p>F\end{array}$ & $\begin{array}{l}<50 \\
\mathrm{~dB}(\mathrm{~A})\end{array}$ & $\begin{array}{l}50-54 \\
d B(A)\end{array}$ & $\begin{array}{l}55-59 \\
d B(A)\end{array}$ & $\begin{array}{l}\geq 60 \\
d B(A)\end{array}$ & $\begin{array}{l}\mathrm{N} \\
\text { total }\end{array}$ & $\begin{array}{l}p\left(x^{2}\right) \text { or } \\
p>F\end{array}$ \\
\hline Age $($ mean $\pm S D)$ & $\begin{array}{l}54.9 \\
(13.0)\end{array}$ & $\begin{array}{l}54.1 \\
(14.4)\end{array}$ & $\begin{array}{l}53.8 \\
(14.6)\end{array}$ & $\begin{array}{l}55.9 \\
(12.3)\end{array}$ & 555 & 0.606 & $\begin{array}{l}50.8 \\
(13.7)\end{array}$ & $\begin{array}{l}52.7 \\
(14.6)\end{array}$ & $\begin{array}{l}52.5 \\
(15.7)\end{array}$ & $\begin{array}{l}54.6 \\
(14.5)\end{array}$ & 745 & 0.083 \\
\hline BMI (mean \pm SD) & $\begin{array}{l}26.8 \\
(4.0)\end{array}$ & $26.7(5.1)$ & $27.5(5.0)$ & $\begin{array}{l}27.4 \\
(4.4)\end{array}$ & 555 & 0.369 & $\begin{array}{l}25.7 \\
(5.2)\end{array}$ & $25.6(5.4)$ & $26.2(5.8)$ & $\begin{array}{l}27.0 \\
(5.6)\end{array}$ & 745 & 0.066 \\
\hline Alcohol (units/week) ${ }^{1}$ & & & & & & 0.006 & & & & & & 0.370 \\
\hline teetotaller & 5.4 & 2.5 & 5.2 & 7.0 & 112 & & 8.1 & 7.4 & 9.1 & 9.9 & 257 & \\
\hline $1-7$ & 15.0 & 14.2 & 9.4 & 14.6 & 295 & & 13.6 & 9.1 & 11.0 & 13.8 & 354 & \\
\hline $8-14$ & 6.5 & 4.0 & 2.3 & 2.9 & 87 & & 4.2 & 4.0 & 3.0 & 3.8 & 111 & \\
\hline$>14$ & 2.5 & 2.2 & 2.3 & 4.0 & 61 & & 1.1 & 0.3 & 1.1 & 0.7 & 23 & \\
\hline $\begin{array}{l}\text { Smoker habits (units/ } \\
\text { day) })^{1}\end{array}$ & & & & & & 0.650 & & & & & & 0.417 \\
\hline non-smoker & 11.5 & 11.2 & 7.9 & 12.8 & 241 & & 13.3 & 12.0 & 14.0 & 16.5 & 415 & \\
\hline exsmoker & 13.0 & 7.8 & 7.4 & 10.6 & 215 & & 8.1 & 3.9 & 4.8 & 6.4 & 173 & \\
\hline $0-10$ & 2.9 & 1.4 & 1.8 & 1.8 & 44 & & 3.1 & 3.0 & 3.1 & 2.8 & 89 & \\
\hline $11-20$ & 1.3 & 1.1 & 1.3 & 1.4 & 28 & & 1.9 & 1.2 & 1.3 & 1.9 & 47 & \\
\hline$>20$ & 0.7 & 1.4 & 0.9 & 1.8 & 27 & & 0.5 & 0.8 & 0.9 & 0.5 & 21 & \\
\hline Education ${ }^{1}$ & & & & & & 0.515 & & & & & & 0.098 \\
\hline 1st qrt & 10.8 & 7.8 & 6.9 & 11.4 & 204 & & 6.7 & 7.4 & 8.3 & 9.8 & 240 & \\
\hline 2nd grt & 5.2 & 3.2 & 3.8 & 4.3 & 92 & & 5.9 & 3.6 & 4.0 & 7.1 & 154 & \\
\hline $3 r d$ qrt & 4.5 & 4.5 & 2.7 & 6.3 & 100 & & 4.8 & 4.0 & 3.9 & 4.6 & 129 & \\
\hline $4 \mathrm{rd}$ qrt & 8.8 & 7.4 & 6.0 & 6.5 & 159 & & 9.4 & 5.8 & 7.9 & 6.7 & 222 & \\
\hline Physical activity ${ }^{1}$ & & & & & & 0.596 & & & & & & 0.003 \\
\hline No or little & 14.4 & 11.5 & 9.9 & 16.0 & 288 & & 12.6 & 10.2 & 14.0 & 17.9 & 407 & \\
\hline Regular & 15.0 & 11.4 & 9.4 & 12.4 & 267 & & 14.2 & 10.6 & 10.2 & 10.3 & 338 & \\
\hline Total & 163 & 127 & 107 & 158 & 555 & & 200 & 155 & 180 & 210 & 745 & \\
\hline
\end{tabular}

${ }^{1}$ Percentage of participants

Table 2 Geometric means (Standard Deviation) for cortisol outcomes by country and by sex-subgroups

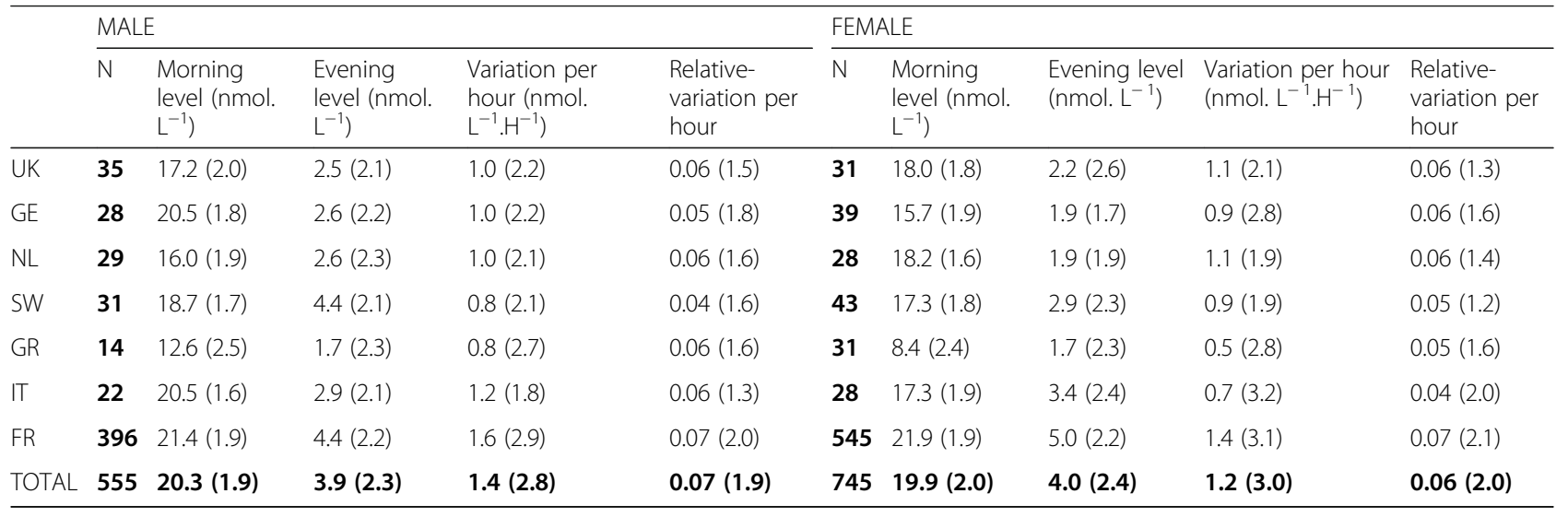


Table 3 Linear regression coefficient after exponentiation for the relation between cortisol outcomes and aircraft noise levels

\begin{tabular}{|c|c|c|c|c|c|c|c|c|c|c|c|c|c|c|c|c|c|}
\hline & & \multicolumn{8}{|l|}{ MALE } & \multicolumn{8}{|c|}{ FEMALE } \\
\hline & & \multicolumn{2}{|c|}{$\begin{array}{l}\text { Morning level } \\
\left(\mathrm{nmol} . \mathrm{L}^{-1}\right)\end{array}$} & \multicolumn{2}{|c|}{$\begin{array}{l}\text { Evening level } \\
\left(\mathrm{nmol} . \mathrm{L}^{-1}\right)\end{array}$} & \multicolumn{2}{|c|}{$\begin{array}{l}\text { Variation per } \\
\text { hour (nmol. } \\
\mathrm{L}^{-1} \cdot \mathrm{H}^{-1} \text { ) } \\
\end{array}$} & \multicolumn{2}{|c|}{$\begin{array}{l}\text { Relative- } \\
\text { variation per } \\
\text { hour } \\
\end{array}$} & \multicolumn{2}{|c|}{$\begin{array}{l}\text { Morning level } \\
\left(n m o l . L^{-1}\right)\end{array}$} & \multicolumn{2}{|c|}{$\begin{array}{l}\text { Evening level } \\
\left(\mathrm{nmol} . \mathrm{L}^{-1}\right)\end{array}$} & \multicolumn{2}{|c|}{$\begin{array}{l}\text { Variation per } \\
\text { hour (nmol. } \\
\mathrm{L}^{-1} \cdot \mathrm{H}^{-1} \text { ) } \\
\end{array}$} & \multicolumn{2}{|c|}{$\begin{array}{l}\text { Relative- } \\
\text { variation per } \\
\text { hour }\end{array}$} \\
\hline & & $\exp (\beta)$ & $\mathrm{Cl} 195 \%$ & $\exp (\beta)$ & Cl95\% & $\exp (\beta)$ & $\mathrm{Cl} 95 \%$ & $\exp (\beta)$ & $\mathrm{Cl} 195 \%$ & $\exp (\beta)$ & Cl95\% & $\exp (\beta)$ & Cl95\% & $\exp (\beta)$ & $\mathrm{Cl} 195 \%$ & $\exp (\beta)$ & Cl95\% \\
\hline \multirow[t]{4}{*}{$\begin{array}{l}\text { Crude } \\
\text { estimates }\end{array}$} & $L_{\text {Aeq, } 16 h}$ & 0.96 & $\begin{array}{l}(0.90- \\
1.02)\end{array}$ & 0.99 & $\begin{array}{l}(0.91- \\
1.07)\end{array}$ & 0.90 & $\begin{array}{l}(0.82- \\
1.00)\end{array}$ & 0.95 & $\begin{array}{l}(0.88- \\
1.01)\end{array}$ & 1.00 & $\begin{array}{l}(0.94- \\
1.07)\end{array}$ & 1.04 & $\begin{array}{l}(0.96- \\
1.13)\end{array}$ & 0.92 & $\begin{array}{l}(0.83- \\
1.01)\end{array}$ & 0.91 & $\begin{array}{l}(0.86- \\
0.97)\end{array}$ \\
\hline & $\mathrm{L}_{\text {Aeq,24h }}$ & 0.95 & $\begin{array}{l}(0.88- \\
1.02)\end{array}$ & 0.98 & $\begin{array}{l}(0.9- \\
1.070)\end{array}$ & 0.90 & $\begin{array}{l}(0.80- \\
1.00)\end{array}$ & 0.95 & $\begin{array}{l}(0.88- \\
1.02)\end{array}$ & 1.02 & $\begin{array}{l}(0.95- \\
1.09)\end{array}$ & 1.06 & $\begin{array}{l}(0.97- \\
1.15)\end{array}$ & 0.93 & $\begin{array}{l}(0.84- \\
1.04)\end{array}$ & 0.92 & $\begin{array}{l}(0.86- \\
0.98)\end{array}$ \\
\hline & $L_{\text {den }}$ & 0.96 & $\begin{array}{l}(0.89- \\
1.03)\end{array}$ & 1.00 & $\begin{array}{l}(0.91- \\
1.09)\end{array}$ & 0.90 & $\begin{array}{l}(0.81- \\
1.01)\end{array}$ & 0.94 & $\begin{array}{l}(0.88- \\
1.01)\end{array}$ & 1.01 & $\begin{array}{l}(0.95- \\
1.08)\end{array}$ & 1.08 & $\begin{array}{l}(1.00- \\
1.18)\end{array}$ & 0.91 & $\begin{array}{l}(0.82- \\
1.02)\end{array}$ & 0.91 & $\begin{array}{l}(0.85- \\
0.97)\end{array}$ \\
\hline & $L_{\text {night }}$ & 1.01 & $\begin{array}{l}(0.94- \\
1.08)\end{array}$ & 1.08 & $\begin{array}{l}(1.00- \\
1.17)\end{array}$ & 0.99 & $\begin{array}{l}(0.89- \\
1.09)\end{array}$ & 0.98 & $\begin{array}{l}(0.92- \\
1.05)\end{array}$ & 1.04 & $\begin{array}{l}(0.97- \\
1.10)\end{array}$ & 1.24 & $\begin{array}{l}(1.15- \\
1.34)\end{array}$ & 0.97 & $\begin{array}{l}(0.87- \\
1.07)\end{array}$ & 0.93 & $\begin{array}{l}(0.88- \\
0.99)\end{array}$ \\
\hline \multirow[t]{4}{*}{$\begin{array}{l}\text { Adjusted } \\
\text { models }^{a}\end{array}$} & $L_{\text {Aeq, } 16 h}$ & 0.99 & $\begin{array}{l}(0.92- \\
1.06)\end{array}$ & 1.04 & $\begin{array}{l}(0.95- \\
1.12)\end{array}$ & 0.95 & $\begin{array}{l}(0.86- \\
1.06)\end{array}$ & 0.97 & $\begin{array}{l}(0.90- \\
1.04)\end{array}$ & 1.04 & $\begin{array}{l}(0.98- \\
1.10)\end{array}$ & 1.08 & $\begin{array}{l}(1.00- \\
1.16)\end{array}$ & 0.95 & $\begin{array}{l}(0.86- \\
1.06)\end{array}$ & 0.92 & $\begin{array}{l}(0.86- \\
0.98)\end{array}$ \\
\hline & $\mathrm{L}_{\text {Aeq,24h }}$ & 0.98 & $\begin{array}{l}(0.91- \\
1.05)\end{array}$ & 1.03 & $\begin{array}{l}(0.94- \\
1.12)\end{array}$ & 0.94 & $\begin{array}{l}(0.84- \\
1.06)\end{array}$ & 0.96 & $\begin{array}{l}(0.89- \\
1.04)\end{array}$ & 1.05 & $\begin{array}{l}(0.98- \\
1.12)\end{array}$ & 1.08 & $\begin{array}{l}(1.00- \\
1.17)\end{array}$ & 0.96 & $\begin{array}{l}(0.86- \\
1.08)\end{array}$ & 0.92 & $\begin{array}{l}(0.85- \\
0.98)\end{array}$ \\
\hline & $\mathrm{L}_{\text {den }}$ & 0.99 & $\begin{array}{l}(0.92- \\
1.06)\end{array}$ & 1.04 & $\begin{array}{l}(0.95- \\
1.14)\end{array}$ & 0.95 & $\begin{array}{l}(0.85- \\
1.06)\end{array}$ & 0.96 & $\begin{array}{l}(0.89- \\
1.04)\end{array}$ & 1.03 & $\begin{array}{l}(0.97- \\
1.10)\end{array}$ & 1.09 & $\begin{array}{l}(1.01- \\
1.18)\end{array}$ & 0.93 & $\begin{array}{l}(0.84- \\
1.04)\end{array}$ & 0.90 & $\begin{array}{l}(0.84- \\
0.97)\end{array}$ \\
\hline & $L_{\text {night }}$ & 1.00 & $\begin{array}{l}(0.93- \\
1.08)\end{array}$ & 1.05 & $\begin{array}{l}(0.97- \\
1.15)\end{array}$ & 0.95 & $\begin{array}{l}(0.85- \\
1.06)\end{array}$ & 0.95 & $\begin{array}{l}(0.88- \\
1.02)\end{array}$ & 1.00 & $\begin{array}{l}(0.94- \\
1.07)\end{array}$ & 1.11 & $\begin{array}{l}(1.02- \\
1.20)\end{array}$ & 0.89 & $\begin{array}{l}(0.80- \\
1.00)\end{array}$ & 0.89 & $\begin{array}{l}(0.83- \\
0.96)\end{array}$ \\
\hline
\end{tabular}

adjusted for country, alcohol intake, smoking habits, physical activity, education level, age and BMI (statistically significant values in bold)

no difference were shown between gender subgroups. Considering the HYENA participants only, statistically significant associations were found only in women, but for an increase in the morning cortisol levels [17]. The HYDE pooled-analyses, providing a greater statistical power, found statistically significant associations between aircraft noise exposure and modification of the cortisol stress-hormone secretion for women only. Moreover, the main finding of this study was the statistically significant associations between noise levels and noise annoyance and the average relative-variation per hour.

The use of relative-variation per hour contributes to a new approach to analysis of cortisol in relation to noise exposure. It also allows for potential measurement differences between HYENA and DEBATS related to sampling and laboratory analysis: the ELISA (enzyme-linked immunosorbent) method in the DEBATS study and the RIA (radioimmunoassay) method in the HYENA. For morning and evening cortisol levels, the use of the linear relationship between ELISA and RIA methods [35] makes levels of cortisol concentrations directly comparable for the HYDE study. Regression conclusions were similar to those presented in Table 3, carried out without the use of this equation.

Although procedures in samplings were similar, differences occurred in the morning sampling which was requested to be collected $30 \mathrm{~min}$ after awakening in HYENA, and directly at awakening in DEBATS. It has been shown that cortisol levels rapidly rise by $50-75 \%$ within the first $30 \mathrm{~min}$ after awakening, and remain elevated for the next 30 min after the peak. This pattern in cortisol secretion has been shown to be independent of time of awakening, sleep quality, sleep duration, and age [42]. However, it seems quite difficult to define precisely when the awakening occurred. If morning cortisol samples were collected before the cortisol peak in the DEBATS study, it is likely that these cortisol levels were lower than the peak level. However, this measurement bias is independent from the noise levels, and could stand for a non-differential measurement error. Thus, it could have led to biased results toward the null value and could explain the fact that no association was observed for morning concentrations. Despite this, a statistically significant association was still observed for morning-evening cortisol variation and average relative cortisol variation per hour.

The present study found statistically significant associations between aircraft noise levels and cortisol outcomes only in women. Even if they were closer to 1, the estimates for males were not so different from that of females, especially for the relative variation per hour. This can either be explained by the fact that the men sample was smaller than the female study sample or by the fact that there was no association in men.

These results are in line with those showing that women were more sensitive to stressors in general [43, 44]. But they are not in line with those of previous studies considering gender-differences and showing statistically significant associations between aircraft or traffic noise exposure and hypertension only in men [5, 36, 45]. As statistically significant associations in women were 
stronger considering aircraft noise levels during the night with the $L_{\text {night }}$, the hypothesis that women have a higher susceptibility to noise during sleep could be relevant. Recent research has pointed out different physiological characteristics in both men and women, leading to differences in the pathogenesis of cardiovascular diseases. Indeed, several studies on the effects of traffic noise exposure on the risk of hypertension showed stronger associations for men [1, 46-48]. This interaction could also explain the findings of the present study concerning the results of analyses in women under and over 50 years of age. Indeed, the associations were stronger in women under 50 years of age, while there was no statistically significant relationship in women over 50 years of age. After 50 years of age, with the disappearance of oestrogens, women's hormonal systems tend to get closer to those of men, thus could explain that the results were almost similar in men and in women after 50 years of age in this study.

Statistically significant associations in women were stronger for aircraft noise levels during the night. These results support the hypothesis that susceptibility to noise would be higher during the night [49]. Sleep duration could be regarded as a confounder or as a mediator in the relation between aircraft noise exposure and the cortisol secretion $[40,50]$, since night-time noise can impact on sleep latency and induce early morning awakenings. Nevertheless, when this variable was included in the models, the results remained very similar, thus excluding the role of confounder or of mediator of sleep duration in the association between aircraft noise levels and cortisol secretion. As restrictions in night traffic concerned every airport except London's Heathrow and Amsterdam Schiphol, we added an interaction term between country and noise exposure levels in multivariate models. Nevertheless, no substantial difference between countries was seen (results not shown). In sensitivity analyses, the results remained similar when the HYENA countries were removed one at a time from analyses. Associations were even stronger when the UK, the country with the highest noise exposure levels, was removed.

Selection bias cannot be excluded in the present study. The low response rate in most of the participating countries may be a potential weakness of this study. However, only minor differences were found between the characteristics of the participants and those of the nonresponders according to aircraft noise exposure categories $[5,36]$. Aircraft noise levels were estimated at home address of each participant, but this may result in some exposure misclassification. It was not possible to take into account their noise exposure outside their home because no information was collected on time schedule and the work or leisure places of each participant. It is more likely that people are in their home at night, so night- time exposure is more likely to be close to the estimated noise level and may be the reason that the strongest associations were observed for $\mathrm{L}_{\text {night }}$. However, as the four noise indicators were highly correlated, this did not allow the effects of noise exposure during the day or at night to be disentangled.

When annoyance from aircraft noise or noise sensitivity were included as confounders in the models, no obvious differences were seen in results. These findings suggest that cortisol variations may be directly connected to aircraft noise exposure rather than mediated through noise annoyance and noise sensitivity.

Noise has been assumed to be a non-specific stress factor activating the autonomic nervous system and endocrine pathway $[12,51]$. Stress is biologically distinguished by the secretion of hormones: catecholamines (norepinephrine, adrenaline) and cortisol [52]. The use of saliva cortisol in this study rather than blood cortisol or cortisol in the urine has been motivated by the fact that it is easy to measure in the general population, by its reliability, rapidity to sample, and non-invasiveness [53]. However, cortisol secretion can be influenced by season, time and week day of sampling [54], sex, age, BMI, physical activity, alcohol consumption, smoking, medication, high food intake, sleep quality, occupational activity, female hormonal contraception, and pregnancy [50] - all factors that affect hormonal balance [55]. All of these factors may moderate the association between aircraft noise exposure and cortisol secretion. Residual confounding bias cannot be excluded in this study but we have tried to minimize it by including all the information we have about these factors in the models.

The findings of the present study support a hypothesis that noise induces stress and are coherent with previous studies finding associations between aircraft noise exposure and hypertension or antihypertensive and anxiolytic medication intake $[5,36,37]$. There is evidence suggesting a role for cortisol in hypertension [56, 57], and other stated for an increase in the cortisol stress response responding to mental stress tasks, thus leading to incident hypertension [58].

\section{Conclusions}

The present results support the hypothesis that exposure to aircraft noise, at night in particular, could make the HPA axis less flexible, especially in women, resulting in higher average values for the evening cortisol concentration, and therefore a flattening of the difference between morning and evening levels. The cause/effect relations and the biological process between noise exposure and HPA dysregulation are of major importance and need to be further elucidated. 


\section{Supplementary information}

Supplementary information accompanies this paper at https://doi.org/10. 1186/s12940-019-0540-0.

Additional file 1: Table S1. Linear regression coefficient after exponentiation for the relation between cortisol outcomes and aircraft noise levels removing in turn one country from the HYENA study. Table S2. Linear regression coefficient after exponentiation for the relation between cortisol outcomes and aircraft noise levels in women under and above 50 years old.

\section{Acknowledgements}

For HYENA study: Thanks to Lars Jarup, HYENA principal investigator and other members of the HYENA study team responsible for conducting the study. Thanks to the aviation administration and the road administration in each of the participating countries for their contribution to the noise exposure assessment.

For DEBATS study: Thanks to the Airport Pollution Control Authority (Acnusa) for requesting the French Institute of Science and Technology for Transport, Development and Networks (Ifsttar) to carry out this study; thanks to Paris Airports and the French Civil Aviation Authority for providing noise exposure maps.

The authors are grateful to all the participants in both HYENA and DEBATS studies and their interviewers. The authors thank Sarah Floud for data extraction and preparation and variable interpretation, and Liacine Bouaoun for his statistical help.

\section{Author's contribution}

For the HYENA consortium: Jenny Selander (JS), Wolfgang Babisch (WB), Ennio Cadum (EC), Konstantina Dimakopoulou (KD), Danny Huithuijs (DH), Göran Pershagen (GP), Töres Theorell (TT), Venetia Velonaki (W) designed and conducted the original HYENA study.

For the DEBATS study: Anne-Sophie Evrard (ASE) and Bernard Laumon (BL) with Jacques Lambert $(J \mathrm{~L})$ and Patricia Champelovier (PC) conceived and designed the DEBATS study. ASE and Marie Lefèvre $(\mathrm{ML})$ conducted the study. $J$ interpreted the aircraft noise data and PC interpreted the annoyance data. ML was involved in data extraction and preparation. Marie-Christine Carlier (MCC) was involved in cortisol determination and data interpretation. For the HYDE analysis: Clémence Baudin (CB), ASE and Anna Hansell (AH) designed the HYDE study, CB performed the statistical analyses, supervised by $A H, A S E$ and $B L$. The analyses were interpreted by $C B, A H$ and $A S E$ with BL, MCC and JS. CB, AH and ASE drafted the initial report. All coauthors revised the report and approved the final version. ASE and $\mathrm{AH}$ are responsible for the overall content as the guarantors of this paper.

\section{Funding}

The HYENA study was funded by a grant from the European Commission (Directorate General Research) in the Fifth Framework Programme, Quality of Life and Management of Living Resources, Key Action 4 - Environment and Health (grant QLRT-2001-02501).

The DEBATS study was supported by funds from the French Ministry of Health, the French Ministry of the Environment, and the French Civil Aviation Authority. The authors would like to thank them for their kind assistance. The HYDE joint-research project was sustained by a grant from the European and International Affairs Department (DAEI) of IFSTTAR (French Institute of science and technology for transport, development and networks).

\section{Availability of data and materials}

Not applicable.

\section{Ethics approval and consent to participate}

The research undertaken by each of the HYENA partners was covered by local agreements concerning the ethical use of data and the protection of confidentiality of individuals. Ethics approvals have been obtained in all partner countries.

The DEBATS study was approved by two national authorities in France: the French Advisory Committee for Data Processing in Health Research and the French National Commission for Data Protection and Liberties.
The HYDE study (titled HYDE project: HYena and DEbats studies) was approved by the University Ethics Sub-Committee of Medicine and Biological Sciences from the University of Leicester.

\section{Consent for publication}

Not applicable.

\section{Competing interests}

The authors declare that they have no competing interests.

\section{Author details}

${ }^{1}$ Univ Lyon, Université Claude Bernard Lyon1, ifsttar, umrestte, umr t_9405, Cité des Mobilités, 25 avenue François Mitterrand, F-69675 Bron, France.

${ }^{2}$ Now at: Technical Agency for Information on Hospital Care, Lyon, France. ${ }^{3}$ Institute of Environmental Medicine, Karolinska Institute, Stockholm, Sweden. ${ }^{4}$ Federal Environment Agency, Berlin, Germany. ${ }^{5}$ Environmental Health Unit, Agency for Health Protection, Pavia, Italy. ${ }^{6}$ Hospices Civils de Lyon GH Sud CBAPS Laboratoire de Biochimie, Pierre Bénite, France.

${ }^{7}$ Currently retired, Bron, France. ${ }^{8}$ IFSTTAR, Planning, Mobilities and Environment Department, Dynamics of Mobility Changes Team, Bron, France. ${ }^{9}$ Department of Hygiene, Epidemiology and Medical Statistics Faculty of Medicine, National and Kapodistrian, University of Athens, Athens, Greece.

${ }^{10}$ National Institute of Public Health and Environmental Protection, Bilthoven, the Netherlands. ${ }^{11}$ IFSTTAR, Transport, Health and Safety Department, Bron, France. ${ }^{12}$ Institute of Environmental Medicine, Karolinska Institute, Stockholm, Sweden. ${ }^{13}$ Stress Research Institute, Faculty of Social Sciences, Stockholm University, Stockholm, Sweden. ${ }^{14}$ Nurses School, National and Kapodistrian, University of Athens, Athens, Greece. ${ }^{15}$ Centre for Environmental Health and Sustainability, University of Leicester, Leicester, UK.

Received: 9 May 2019 Accepted: 28 October 2019

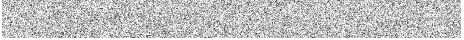

\section{References}

1. van Kempen E, Casas M, Pershagen G, Foraster M. WHO environmental noise guidelines for the European region: a systematic review on environmental noise and cardiovascular and metabolic effects: a summary. Int J Environ Res Public Health. 2018 Feb;22:15(2).

2. Babisch W, Houthuijs D, Pershagen G, Cadum E, Katsouyanni K, Velonakis M, et al. Annoyance due to aircraft noise has increased over the years--results of the HYENA study. Environ Int. 2009 Nov;35(8):1169-76.

3. Perron S, Tétreault L-F, King N, Plante C, Smargiassi A. Review of the effect of aircraft noise on sleep disturbance in adults. Noise Health. 2012 Apr; 14(57):58-67.

4. Hansell AL, Blangiardo M, Fortunato L, Floud S, de Hoogh K, Fecht D, et al. Aircraft noise and cardiovascular disease near Heathrow airport in London: small area study. BMJ. 2013;347:f5432.

5. Evrard A-S, Lefèvre $M$, Champelovier $P$, Lambert J, Laumon B. Does aircraft noise exposure increase the risk of hypertension in the population living near airports in France? Occup Environ Med. 2017;74:123-9.

6. Evrard A-S, Bouaoun L, Champelovier P, Lambert J, Laumon B. Does exposure to aircraft noise increase the mortality from cardiovascular disease in the population living in the vicinity of airports? Results of an ecological study in France. Noise Health. 2015 Oct;17(78):328-36.

7. Nassur A-M, Lefèvre M, Laumon B, Léger D, Evrard A-S. Aircraft noise exposure and subjective sleep quality: the results of the DEBATS study in France. Behav Sleep Med. 2017;27:1-12.

8. Haines MM, Stansfeld SA, Brentnall S, Head J, Berry B, Jiggins M, et al. The West London schools study: the effects of chronic aircraft noise exposure on child health. Psychol Med. 2001;31(8):1385-96.

9. Stansfeld SA, Berglund B, Clark C, Lopez-Barrio I, Fischer P, Ohrström E, et al. Aircraft and road traffic noise and children's cognition and health: a crossnational study. Lancet. 2005;365(9475):1942-9.

10. Lundberg U. Coping with stress: neuroendocrine reactions and implications for health. Noise Health. 1999;1(4):67-74.

11. Spreng M. Central nervous system activation by noise. Noise Health. 2000; 2(7):49-58.

12. Babisch W. Stress hormones in the research on cardiovascular effects of noise. Noise Health. 2003;5(18):1-11.

13. Born J, Fehm HL. The neuroendocrine recovery function of sleep. Noise Health. 2000;2(7):25-38. 
14. Beck JC, McGARRRY EE. Physiological importance of cortisol. Br Med Bull. 1962;18:134-40.

15. Horrocks PM, Jones AF, Ratcliffe WA, Holder G, White A, Holder R, et al. Patterns of ACTH and cortisol pulsatility over twenty-four hours in normal males and females. Clin Endocrinol. 1990 Jan;32(1):127-34.

16. Aardal $E_{1}$ Holm AC. Cortisol in saliva--reference ranges and relation to cortisol in serum. Eur J Clin Chem Clin Biochem J Forum Eur Clin Chem Soc 1995;33(12):927-32.

17. Selander J, Bluhm G, Theorell T, Pershagen G, Babisch W, Seiffert I, et al. Saliva cortisol and exposure to aircraft noise in six European countries. Environ Health Perspect. 2009;117(11):1713-7.

18. Stokholm ZA, Hansen ÅM, Grynderup MB, Bonde JP, Christensen KL, Frederiksen TW, et al. Recent and long-term occupational noise exposure and salivary cortisol level. Psychoneuroendocrinology. 2014 Jan;39:21-32.

19. McEwen BS, Seeman T. Protective and damaging effects of mediators of stress. Elaborating and testing the concepts of allostasis and allostatic load. Ann N Y Acad Sci. 1999;896:30-47.

20. Hajat A, Diez-Roux A, Franklin TG, Seeman T, Shrager S, Ranjit N, et al. Socioeconomic and race/ethnic differences in daily salivary cortisol profiles: the multi-ethnic study of atherosclerosis. Psychoneuroendocrinology. 2010; 35(6):932-43.

21. Ranjit N, Young EA, Kaplan GA. Material hardship alters the diurnal rhythm of salivary cortisol. Int J Epidemiol. 2005;34(5):1138-43.

22. Desantis AS, Kuzawa CW, Adam EK. Developmental origins of flatter cortisol rhythms: socioeconomic status and adult cortisol activity. Am J Hum Biol Off J Hum Biol Counc. 2015;27(4):458-67.

23. Eriksson C, Pershagen G. Biological mechanisms related to cardiovascular and metabolic effects by environmental noise [internet]: WHO; 2018 Available from: http://www.euro.who.int/en/health-topics/environment-andhealth/noise/publications/2018/biological-mechanisms-related-tocardiovascular-and-metabolic-effects-by-environmental-noise

24. Jarup L, Dudley M-L, Babisch W, Houthuijs D, Swart W, Pershagen G, et al. Hypertension and exposure to noise near airports (HYENA): study design and noise exposure assessment. Environ Health Perspect. 2005;113(11): $1473-8$.

25. Lefèvre M, Carlier M-C, Champelovier $P$, Lambert J, Laumon B, Evrard A-S. Effects of aircraft noise exposure on saliva cortisol near airports in France. Occup Environ Med. 2017;74(8):612-8.

26. Airport Council International. TOP 30 European airports 2013 [Internet]. [cited 2019 Mar 11]. Available from: https://www.aci-europe.org/policy/ position-papers.html?view=group\&group $=1$ \&id $=11$

27. Ennis M, Kelly KS, Lambert PL. Sex differences in cortisol excretion during anticipation of a psychological stressor: possible support for the tend-andbefriend hypothesis. Stress Health. 2001;17(4):253-61.

28. He B, Dinges E, Hemann J, Rickel D, Mirsky L, Roof CJ, et al. Integrated Noise Model (INM) Version 7.0 User's Guide. 2007 Apr [cited 2017 Mar 17]; Available from: https:/trid.trb.org/view.aspx?id=1355724

29. R\&D Report 9842: The UK Civil Aircraft Noise Contour Model ANCON Improvements in Version 2 [Internet]. [cited 2018 Dec 18]. Available from: http://publicapps.caa.co.uk/modalapplication.aspx?catid=1\&pagetype=65 \&appid $=11$ \&mode $=$ detail\&id $=784 \&$ filter $=2$

30. Ollerhead JB. The CAA Aircraft Noise Contour Model : ANCON Version 1; 1994.

31. Orders T, He FAA. Integrated Noise Model (INM) Version 7.0 User's Guide 2007 [cited 2017 Mar 15]; Available from: https://ntl.bts.gov/lib/54000/54 900/54923/INM 7.0 User_Guide.pdf

32. Directive 2002/49/CE du Parlement européen et du Conseil du 25 juin 2002 relative à l'évaluation et à la gestion du bruit dans l'environnement Déclaration de la Commission au sein du comité de conciliation concernant la directive relative à l'évaluation et à la gestion du bruit ambiant [Internet]. [cited 2018 Mar 21]. Available from: https://eur-lex.europa.eu/legal-content/ $\mathrm{fr} /$ ALL/?Uri=CELEX:32002L0049

33. Fields JM, De jong RG, Gjestland T, Flindell IH, RFS j, Kurra S, et al. Standardized general-purpose noise reaction questions for community noise surveys: research and a recommendation. J Sound Vib. 2001;242(4): $641-79$

34. Worthington DL. Weinstein Noise Sensitivity Scale (WNSS). In: The Sourcebook of Listening Research [Internet]. John Wiley \& Sons, Ltd; 2017. p. 475-481. Available from: https://onlinelibrary.wiley.com/doi/abs/10.1002/ 9781119102991.ch52, [cited 2019 Mar 11]
35. Baecher S, Azad SC, Vogeser M, Speichel M, im d C. Inter-method comparison of salivary cortisol measurement; 2013.

36. Jarup L, Babisch W, Houthuijs D, Pershagen G, Katsouyanni K, Cadum E, et al. Hypertension and exposure to noise near airports: the HYENA study. Environ Health Perspect. 2008 Mar; 116(3):329-33.

37. Floud $S$, Vigna-Taglianti F, Hansell A, Blangiardo M, Houthuijs D, Breugelmans $\mathrm{O}$, et al. Medication use in relation to noise from aircraft and road traffic in six European countries: results of the HYENA study. Occup Environ Med. 2011;68(7):518-24.

38. Kroesen M, Molin EJE, van Wee B. Testing a theory of aircraft noise annoyance: a structural equation analysis. J Acoust Soc Am. 2008;123(6): 4250-60.

39. Babisch W, Pershagen G, Selander J, Houthuijs D, Breugelmans O, Cadum E, et al. Noise annoyance -a modifier of the association between noise level and cardiovascular health? Sci Total Environ. 2013:452-453:50-7.

40. Wallas A, Eriksson C, Gruzieva O, Lind T, Pyko A, Sjöström M, et al. Road traffic noise and determinants of saliva cortisol levels among adolescents. Int J Hyg Environ Health. 2018;221(2):276-82.

41. Smith A. The concept of noise sensitivity : implications for noise control. Noise Health. 2003:5(18):57.

42. Pruessner JC, Wolf OT, Hellhammer DH, Buske-Kirschbaum A, von Auer K, Jobst S, et al. Free cortisol levels after awakening: a reliable biological marker for the assessment of adrenocortical activity. Life Sci. 1997;61(26):2539-49

43. Alderling M, Theorell T, de la Torre B, Lundberg I. The demand control model and circadian saliva cortisol variations in a Swedish population based sample (the PART study). BMC Public Health 2006;6(1):288.

44. Hasson D, Theorell T, Bergquist J, Canlon B. Acute stress induces hyperacusis in women with high levels of emotional exhaustion. PLoS One. 2013:8(1):e52945.

45. Eriksson C, Bluhm G, Hilding A, Ostenson C-G, Pershagen G. Aircraft noise and incidence of hypertension-gender specific effects. Environ Res. 2010 Nov: 1 10(8):764-72

46. Mosca L, Barrett-Connor E, Wenger NK. Sex/gender differences in cardiovascular disease prevention: what a difference a decade makes. Circulation. 2011;124(19):2145-54

47. Dunlay SM, Roger VL. Gender differences in the pathophysiology, clinical presentation, and outcomes of ischemic heart failure. Curr Heart Fail Rep. 2012;9(4):267-76.

48. Pyko A, Lind T, Mitkovskaya N, Ögren M, Östenson C-G, Wallas A, et al. Transportation noise and incidence of hypertension. Int J Hyg Environ Health. 2018;221(8):1133-41.

49. Haralabidis AS, Dimakopoulou K, Velonaki V, Barbaglia G, Mussin M, Giampaolo M, et al. Can exposure to noise affect the $24 \mathrm{~h}$ blood pressure profile? Results from the HYENA study. J Epidemiol Community Health. 2011;65(6):535-41.

50. Kudielka BM, Hellhammer DH, Wüst S. Why do we respond so differently? Reviewing determinants of human salivary cortisol responses to challenge. Psychoneuroendocrinology. 2009;34(1):2-18.

51. Babisch W. The noise/stress concept, risk assessment and research needs. Noise Health. 2002:4(16):1.

52. Maheu FS, Lupien SJ. Memory in the grip of emotions and stress: a necessarily harmful impact? Med Sci MS. 2003;19(1):118-24

53. Keil MF. Salivary cortisol: a tool for biobehavioral research in children. J Pediatr Nurs. 2012;27(3):287-9.

54. Miller R, Stalder T, Jarczok M, Almeida DM, Badrick E, Bartels M, et al. The CIRCORT database: reference ranges and seasonal changes in diurnal salivary cortisol derived from a meta-dataset comprised of 15 field studies. Psychoneuroendocrinology. 2016;73:16-23.

55. Strahler J, Skoluda N, Kappert MB, Nater UM. Simultaneous measurement of salivary cortisol and alpha-amylase: application and recommendations. Neurosci Biobehav Rev. 2017;83:657-77

56. Kelly JJ, Mangos G, Williamson PM, Whitworth JA. Cortisol and hypertension. Clin Exp Pharmacol Physiol Suppl. 1998;25:S51-6.

57. Ahmed N, de la Torre B, Wahlgren NG. Salivary cortisol, a biological marker of stress, is positively associated with 24-hour systolic blood pressure in patients with acute ischaemic stroke. Cerebrovasc Dis Basel Switz. 2004; 18(3):206-13. 
58. Hamer M, Steptoe A. Cortisol responses to mental stress and incident hypertension in healthy men and women. J Clin Endocrinol Metab. 2012 Jan 1;97(1):E29-34.

\section{Publisher's Note}

Springer Nature remains neutral with regard to jurisdictional claims in published maps and institutional affiliations.

Ready to submit your research? Choose BMC and benefit from:

- fast, convenient online submission

- thorough peer review by experienced researchers in your field

- rapid publication on acceptance

- support for research data, including large and complex data types

- gold Open Access which fosters wider collaboration and increased citations

- maximum visibility for your research: over $100 \mathrm{M}$ website views per year

At BMC, research is always in progress. 